no member of the Association who is not capable of helping the cause in some way or other. The need of helpers is great, and offers or inquiries will be very gladly entertained by either the local organisers or by myself.

The three Scandinavian kingdoms have each their Survey, and through them work of the greatest value to the historian has been done and is still being done. England has an incomparably greater wealth of early material, greater than that of any other nation in Western Europe. It is for us to show that we value our proud position in this matter and make the fullest use possible of the material which our forefathers have left us.

ALLEN MaWer.

The University,

Liverpool.

(Director of the Survey.)

\title{
A Herodotean Episode in the History of Novgorod.
}

Madam,-The story of the slaves who took advantage of their masters' absence at the wars to marry their masters' wives and seize the state was already a commonplace of Greek legendary history by the fifth century B.c., and versions of it are connected with Argive history and with the foundation of Tarentum (Annual British School at Athens, xvi. 213). It is also told by Herodotus of the Scythian invaders of Asia (Herodotus, iv. 1-4). The army was twenty-one years away from Scythia. The wives consorted with the slaves during their husbands' absence and a new generation had grown up. The slaves and their progeny dug a great ditch from the Tauric Hills to the Maiotic Sea at its widest point and prepared to dispute the return of their masters. After some inconclusive fighting one of the Scythians suggested putting aside their arms and attacking the slaves with whips. At the sight of these familiar instruments of punishment the "slaves by nature," as Aristotle would have called them, incontinently ran away. The great ditch mentioned in the story has never been satisfactorily identified; some have thought that it referred to a trench across the Crimea, others that it was an explanation of the origin of the Putrid Sea (see How and Wells, Commentary on Herodotus, Macan and Stein, ad loc.).

Giles Fletcher (Of the Russe Commonwealth, ed. Bond (Hakluyt Soc., 1856), pp. 17-18; Hakluyt, Voyages and Travels (Glasgow, 1903), vol. iii. p. 372), who visited Russia in 1588, was told that this Slave War belonged to the history of Novgorod. Clearly he recognised the Herodotean source, for he speaks of "the memorable warre so much spoken of in stories of the Scythian servants, that took armes against their masters." The latter had been long absent on an expedition against the Tartars. Meeting with opposition from the slaves on their return, the masters, " advising what was best to be done, agreed all to set upon them with no other show of weapon but with their horsewhips (which as their maner is every man rideth withal), to put them in remembrance of their servile condition, thereby to terrifie them and abate their courage. And so marching on and lashing al together with their whips in their hands they gave the onset, which seemed so terrible in the eares of their villaines and stroke such a sense into them of the smart of the whip which they had felt before, that they fled altogether like sheepe before the drivers. In memory 
of this victory the Novogradians ever since have stamped their coins (which they cal a dingoe Novogrodsky currant through al Russia) with the figure of a horseman shaking a whip aloft in his hand."

At first sight it would be tempting to believe that the story became localised at Novgorod in the course of the sixteenth century, owing to a misinterpretation of the coin type. The local tradition, how. ever, is probably older than the coin. The type representing a galloping horseman waving his sword, to which Fletcher clearly refers, was first minted at Pskow, not at Novgorod, by Vasili Ivanovitch (1510-1533), the father of Ivan the Terrible (Engel and Serrure, Traité de Numismatique du Moyen Age, iii. (Paris, 1905), p. 1394). Sigismund von Herbertstein, who was in Russia from 1517 to 1526, quite correctly reports that the denga of Novgorod in his day represented a prince on the throne and a man making obeisance to him (Rerum Moscoviticarum Commentarii, in Notes upon Russia, ed. R. H. Major (Hakluyt Soc., 1852), i. 109). But he also heard the story of the Slave War in Novgorod, though he betrays no knowledge that it has been told before by Herodotus (ibid., ii. pp. 26-7), and states that "it is related in their annals." According to him the people of Novgorod were away for seven years besieging the Greek city of Corsun. Upon their return the slaves who had married their mistresses were defeated with "thongs and ropes," and fled to a town henceforward named Chloppigrod, "the Slaves' Fortress." The story is supported by the evidence of the "great bell, which we ourselves saw in their cathedral church," which together with the bronze gates of Corsun had been brought back by the victorious masters. The identification of the town of Chloppigrod appears to be as elusive as that of the great ditch (ibid., ii. 32, note), and Professor Boswell kindly tells me that its existence may be regarded as mythical. He also pointed out to me that the story of the capture of Corsun can only refer to the conquest of Chersonesus by Vladimir I, Grand Duke of Kief (956-1015), who Christianised Russia. The chronicler, or more probably the guide who showed Herbertstein the great bell (there appears to be no reference to the story in The Chronicle of Novgorod, trans. Michel and Forbes (Camden Soc., 1914)), of course had no justification in claiming the credit of this victory for Novgorod. Is it possible that the slave story became attached to this campaign through a confused memory of a celebrated retort of Ragnilda, daughter of the Prince of Potolsk, who, when her hand was demanded by Vladimir, haughtily refused marriage "with the son of a bondswoman"? I fear I am too ignorant of Russian history to probe the matter further with any prospects of success, but it seemed a curiosity worth bringing to the attention of scholars who are better equipped that a story certainly taken from the pages of Herodotus should have been securely incorporated in the local history of Novgorod by the beginning of the sixteenth century. W. R. HaLLIDAY.

The University, Liverpool.

\section{Research in Turkish and Greek History.}

Madam,-Will you allow me to inquire, through your columns, whether any of your readers would be interested to co-operate in some organised study of Western influence on Near and Middle Eastern peoples? 